\title{
A Sociocultural Approach to Children's Visual Creations
}

\begin{abstract}
This chapter locates the book within the research on children's art. It explores interpretations of children's visual creations throughout the twentieth century and situates the approach of the book within the research landscape. The authors take developmental psychological, educational, and aesthetic approaches to form a sociocultural view of children's art, challenging many of the previous research assumptions. Through adopting the paradigm of the sociocultural approach, the authors embrace its view of children as competent cultural actors and active participants in cultural production. Thus, the discussion focuses on meaning-making: the authors analyze visual artifacts made by students to understand how they engage with the idea of the difference.
\end{abstract}

Keywords Sociocultural approach · Visual creations - Power · Participation - Voice

\section{DiffERENT STRANDS OF RESEARCH on Child ARt and CHILdRen's Drawings}

Child art has generated much research since it was defined as a field of interest in the late nineteenth century. At that point, following a romantic

T. Lähdesmäki et al., Learning Cultural Literacy through

Creative Practices in Schools, https://doi.org/10.1007/978-3-030-89236-4_2 
view of childhood as a time of innocence separated from adulthood, children's drawings came to be seen as valuable illuminations of the inner life of children as well as proof of a primitive state preceding adult intellectual enlightenment (Golomb 1993, 11). One of the first to research child art was the Italian archeologist and art historian Corrado Ricci. In the 1880s he collected and analyzed child art, which he found crude and inaccurate, but striving for a sort of "literal completeness" that manifested itself in, for example, the depiction of a horse with both the rider's legs visible from one side. Earl Barnes, an American teacher educator and early contributor to the child study movement similarly contributed to the formation of the field by arguing that children's art was a language of its own, with symbols expressing ideas (French 1956, 327-329). In the twentieth century a plethora of researchers followed these early initiatives and studied children's drawings from an artistic, educational, or psychological point of view. Most of them instrumentalized children's drawings and saw them as expressions of artistic or cognitive development, or, as a means to discover mental issues. For a long time, child study has been dominated by a developmentalist frame, which still influences much of the research on art made by children.

Research on child art can be roughly divided into psychoanalytic/psychological, pedagogical, aesthetic, and sociocultural approaches. For psychoanalysts, art has been a therapeutic practice as well as a means to discover the "inner conflicts" and "disturbing influences" of the child's development (Nikoltsos 2001, 3). Psychological perspectives generally adhere to a developmental frame and use children's drawings to trace how a child matures from a less differentiated "scribble" phase toward more skilled, more realistic expression, also known as visual realism. This strand of research was greatly influenced by the work of the Swiss psychologist Jean Piaget: In 1936 he postulated a correspondence between children's drawings and their spatial-mathematical reasoning. Before this, the US psychologist Florence Goodenough had already created her well-known "draw a man test," which was used to measure children's intellectual abilities (Golomb 1993, 12). Newer studies on developmental and geographic biases about children's drawings attest to the continuing dominance of such universalist, developmental views. For instance, Justin Ostrofsky $(2015,3)$ states that face drawings produced by children aged $3-11$ all around the world show the same "representational flaws" depicting the head "too round" and the eyes "too high up in the head." 
Developmental psychology has influenced many pedagogues, although some have tried to shift the emphasis from lack and deficit to recognition of representational efforts. Viktor Lowenfeld, an Austrian American art educator, saw art as a means to further intellectual and emotional growth. In Creative and Mental Growth (1957), Lowenfeld characterized child art following developmental stages and promoted educational approaches tailored to the individual child's needs. He advocated the use of different kinds of art and artistic activities to support children's growth and favored free expression. His focus on the therapeutic aspects of art education also reveals an adherence to psychoanalytic approaches. Rudolf Arnheim, a German-born art theorist and perceptual psychologist likewise promoted an art educational view and criticized views that saw artistic activity "mainly as an instrument for exploration of the human personality" (Arnheim 1954, 3). He argued that children seek creative solutions to difficult graphic problems and proposed that drawing develops by its own intrinsic logic that does not merely mirror other intellectual domains. In Arnheim's view, even very young children's drawings reveal perception, creative intelligence, and sensitivity to form (a sensitivity found at all developmental levels). All in all, these educational approaches, which may also be termed art based or aesthetic, seek to develop the child's artistic skill. In such a view the creative process is more important than the result (Nikoltsos 2001, 6-8).

Members of the modernist art movement saw child art as a catalyst for creativity. Many modern artists such as Klee, Kandinsky, Miro, and Picasso were inspired by child art and sought to copy its innocent, instinctive expressiveness. To them, child art provided a point of view unconditioned by cultural influences (Leeds 1989; Fineberg 1998). Intrigued by this idea of the innocent eye, the Austrian artist and teacher Franz Cižek, who coined the term "child art," lamented the "alien influences" of cinemas and theaters on the authenticity and creativity of the child (Coates and Coates 2011, 86-87). The idea of the innocent eye still manifests itself in contemporary debates about what proper media content is like (Ivashkevich 2009, 52-54).

In our study, we discard ideas about corrupting cultural influences to maintain that even very young children know how to decode and reuse the signs and symbols circulating within their respective cultural landscapes. This view is based on a rather new trend within research on child art. Toward the end of the twentieth century, the developmentalist framework became increasingly criticized for its focus on skill and its alignment 
with dominant Western cultural expectations (i.e., realism as the highest achievement of visual art, see Einarsdottir et al. 2009, 218). Researchers have, for example, criticized the subordinate status of drawing and play to reading and writing in school curricula: Drawing, in their view, is "an intrinsically valuable form of abstraction and communication, as a social practice, and as a symbolic means of bridging home and school contexts" (Wood and Hall 2011, 270). Recently, socioculturally oriented researchers have begun to examine the contexts of drawing, the narratives around it, and the manner in which drawings, embedded in talk, express meaning (e.g., Cox 2005; Einarsdottir et al. 2009; Deguara 2015). In this strand of research, drawing is used to gain access to children's lived experiences and the ways that they make meaning. This sociocultural strand of research provides an alternative, context-specific, and process-centered approach that takes into consideration the power struggles influencing the production and analysis of children's drawings (see Ivashkevich 2009). Furthermore, it regards drawing as a stage in active identity formation and play (Wood and Hall 2011).

In what follows, we clarify our sociocultural approach to artifacts created by students around Europe and in Israel, which we use to capture children's views on cultural differences and their dialogic navigation. To conclude we discuss the power relations that influence this research constellation.

Before we move on, we need to include some notes on terms. Unlike children's literature, which is created for children, child art is made by children. Yet, this term poses multiple conceptual problems. The first one is the concept of the "child." All humans under 18 could generally be defined as children, yet there is a significant difference between the visual creations of 4-year-olds and 15-year-olds. Developmental psychologists and modern artists alike have observed that "loud and gaudy" childish freedom (terms by French 1956) tends to give way to more norm-bound, "correct" representation as a person grows. Second, conceptualizations of art itself vary from institutional to naturalistic ones (Venäläinen 2019). Since most research on child art has focused on drawings, many researchers have adopted the term "children's drawings" to avoid any conceptual haziness related to the term child art. In this study, we have chosen to speak about students' visual creations or artifacts (following e.g., Deguara and Nutbrown 2018). Sometimes we also refer to them as data. One reason for this terminological choice is the fact that the visual items we examine have been produced in school 
contexts. Hence, the makers were creating their artifacts in the role of students, as part of school work, following certain guidelines or tasks. That is, the artifacts were not created in a purely aesthetic noninstrumental sense (naturalistic view of art). Nor were they created by educated artists (institutional view; see Venäläinen 2019). Talking about "drawings" alone would also not be accurate as various media were used, including audiovisual expression, 3D installation, and text. By calling the creations artifacts, we position them as objects of special interest, worth displaying and studying. By talking about them as data, we refer to them as instruments of research, valuable mostly as a bulk or corpus, as items whose makers remain anonymous. In what comes to the makers of these artifacts, we use the terms "students," "children," "young people," and "age groups." Whenever necessary, we also refer to the country in which the student made the artifact.

\section{A Sociocultural Approach TO STUDENT-MADE ARTifacts}

The past 30 years have seen a rise in sociologically oriented research on children and childhood (James and Prout 1997; Mayall 2002; Tisdall and Punch 2012). This "new" branch of childhood studies emphasizes children's agency and social roles and promotes an understanding of children as beings instead of becomings, that is, as subjects in their own right instead of merely individuals in the process of growing up (Qvortrup 1994). This branch of research challenges developmentalist and educational views in an attempt to understand children's experiences of and effects on the social realities that they live in. Methods used in it include observation, interview, questionnaires, structured activities (such as our reading and discussing picture books/short films), and multisensory approaches such as drawing (Clark 2005). Studies that use drawings as a means to access children's experiences cover topics such as children's reflections on how they have changed during their first year at school, or what they like or dislike in school (Einarsdottir et al. 2009). In these studies, the focus is often on narratives and meaning-making (Cox 2005; Coates and Coates 2011; Deguara 2015).

We emphasize the cultural aspects of such meaning-making. Following William Corsaro's (1992) idea of interpretive reproduction, we maintain that children creatively appropriate information from the adult world through their participation in cultural routines. They do not passively 
repeat or reflect the culture around them. Rather, they borrow, recycle, or reinterpret familiar representations and ideas in a creative manner. In this sense, children's art is connected to broader codes of cultural representation and signification. In cultural studies, representation is understood as a process, in which meanings are created and assigned to images, objects, and people (see e.g., Kellner 1995; Hall 1997). Children's artifacts contribute to the process of cultural representation, recycling culturally acknowledged symbols and meanings while producing new ones. The aesthetic choices made in a drawing can thus be compared to rhetorical choices in speech. As Neil Cohn $(2014,103)$ states, drawing "provides a method to communicate our thoughts in the visual-graphic modality." As such, a drawing —or, in our case a visual artifact—reflects the cultural frames that surround it.

If semiotics is concerned with tracing how marks on paper become signs that represent meaning, social semiotics considers the social settings of such meaning-making events (see e.g., Kress and van Leeuwen 2006; Hopperstad 2008; Deguara and Nutbrown 2018). Our study adheres to this approach in that we look at how the artifacts represent things and communicate ideas in the specific social/cultural settings of schools, classrooms, and peer groups. Specifically, we trace how the students who participated in the Cultural Literacy Learning Programme (CLLP) use signs, symbols, and schemas to communicate their knowledge and understanding of cultural literacy themes such as empathy and tolerance. In this, we assume that drawing (among other visual means of expression) may be used to graphically convey concepts and ideas.

Similarities in the drawings may be traced back to the influence of peers and teachers. Noting these similarities is important, as peers and possible play frames may sometimes be more influential than the pedagogical frames presented by the teacher and the task. In these cases, the resulting artifact communicates the student's other interests or play, instead of their ideas on the given task (i.e., the teacher's or the project's interests). As our analysis establishes, children in a specific class have created their artifacts or described them in strikingly similar ways. We do not see such copying or direct referencing of the cultural texts (short films and picture books) or other students' work as problematic. Rather, it is a sign of dialogic interactions and proof of learning (Cohn 2014; Mavers 2011).

Below, we consider how the classroom context places possible limits on the students' expressive freedom. This is partly related to how semiotic resources are acquired. Children in their early, preschool years enjoy 
both a greater and lesser freedom of expression: Greater in that "they have not yet learned to confine the making of signs to the culturally and socially facilitated media" and lesser, in that "they do not have such rich cultural semiotic resources available as do adults" (Kress and van Leeuwen $2006,9)$. Another significant factor that could inhibit creativity is the influence of classroom hierarchies and the power relations that determine each individual's role in a project such as this. As such, our approach can be described as a critical approach to reading images, "an approach that thinks about the visual in terms of the cultural significance, social practices and power relations in which it is embedded" (Rose 2001, 3).

As we trace how the students navigate the ground of cultural difference (broadly understood as encompassing different points of view and distinctions between an "us" and a "them") it is worth noting what earlier researchers have said about the role of drawing in identity formation. Children create and explore a range of alternative identities (past, present, and future) through their drawings (Deguara 2015, 380). Transitions and achievements in identity are common themes of children's drawings next to the pop cultural influences visible in depictions of cartoons, popstars, and superheroes (Clark 2005, 497-498; Coates and Coates 2011, 9798). Many researchers have observed variations "specific and typical of the children's lives and the social, historical and cultural local context" (see Gernhardt et al. 2013; Senzaki et al. 2014; Deguara 2015, quote by Deguara 2015, 379). For example, some found that children who live near mountains are more likely to draw mountains (Ahmad 2018) and that boys are more likely to represent violence than girls (Kiil 2009). Scholars who compared cultural variations in cognitive processes between Japanese and US children's artwork state "the members of a given culture produce cultural products - tangible, public, shared representations of culture - that convey dominant cultural ideologies" (Senzaki et al. 2014, 1298).

Our approach both builds on and deviates from these sociocultural or culturally sensitive approaches and the research on cultural differences in children's drawings. We draw on these approaches, in that we focus on the context in which the artifacts were made and in that we regard them as means to access the children's ideas. We deviate from the research on cultural differences as we do not distinguish between the different nationalities (or genders etc., though we mention these when relevant) of children who participated in the project. Rather, we are interested in 
how the students express their ideas on cultural difference and the dialogic engagement that helps them to navigate these differences.

\section{Our Approach to Power Relations}

As many of the sociologically oriented researchers of children and childhood have noted, accessing children's ideas is not easy. Even the most sensitive participatory methods cannot overcome the power relations that determine children's marginalized roles in today's sociocultural landscapes. Hence, it is appropriate to discuss some of the problems that our project faces in trying to uncover the student's ideas via visual expressions.

Donna Haraway (1991) and others have argued that all knowledge is limited by the social, cultural, and historical context of its production. This context includes the disciplinary practices and theoretical framework of each study and the positions of power that govern the object-subject relations of empirical research. To put it simply, it is only possible to gain objective scientific knowledge by recognizing the limits or "partial visions" of knowledge production (Haraway 1991, 190-191). This does not denote relativism, but critical scrutiny of the researcher's own positionality in the research process (ibid.). It is essential to be explicit about the reasoning behind choices made, which is why we take into account the contexts in which our participants produce their artifacts and in which we analyze them.

First, the students made their artifacts in a lesson planned and implemented within the broader framework of a research project. The Dialogue and Argumentation for Cultural Literacy Learning in Schools (DIALLS) project is funded by the European Union. Hence, its objective is to solve problems related to cultural encounters within Europe, using educational practices designed to further the EU's agenda on cultural diversity. Second, the artifacts are framed by the school context, including the influence of teachers and peers. As Pohjakallio and Pusa (2019, 22) note, children's school art is framed by the expectations of adults. Karolina Kiil (2009), who has researched forbidden images in adolescent's art classes in Estonia and Finland, lists some of the themes that were considered inappropriate in the school contexts that she studied. These themes included signs of ideology (such as symbols of Nazism or religion), race, ethnic violence, bullying, and negative stereotypes (Kiil 2009, 200-212). Third, and lastly, the artifacts are framed by the researchers' respective gazes. The researchers analyzing the student-made artifacts in this book take 
approaches common to their fields of expertise, education, and cultural studies. They use power when deciding which signs are relevant and how to interpret them.

Whose voice is heard is an important aspect of power relations. As Allison James $(2007,262)$ notes, the idea of listening to children's voices has become a "powerful and pervasive mantra for activists and policy makers worldwide" since the UN declaration on the Rights of the Child. Yet it is not easy to uncover children's ideas (as stated in their own voice) and doing so does not necessarily contribute to sharing power or furthering equality. Like Haraway, James thus urges childhood researchers to practice "awareness of the power differentials involved in the researcher-researched relationship," including an awareness of the fact that children's voices do not represent another kind of "truth" or "authenticity" (ibid.). Researchers should, for instance, pay attention to how often they ask the children leading questions.

The uneven power relations in our project are also visible in how the data has been presented to the researchers. For example, a teacher of the youngest age group of children in Israel reported the outcomes of the home and belonging lesson of the CLLP as follows:

The kids tell us: At first, we painted what a house was for us, we thought and we knew that a house was where we lived.

Then we watched a video about Baboon living on the moon and found out that he misses the earth and whoever is in it. Thanks to the video and seeing that the Baboon is sad we understood that home is a good place to miss.

If we are not with our family they will miss us and we will [miss them].

Talking to friends helped us understand what a home is for them and also better understand what a home is for us.

Our second painting was different from the first one because we understood well what a home is for us. Home is not always the place itself, but it's where the family and people make us feel comfortable and good.

According to the teacher, the program helped the children develop an understanding of the concepts of home and belonging. In particular, it helped the students move from an understanding of home as a house that they live in, to an understanding of home as more than a place. While this development could have occurred, the coherence in the teacher's narrative raises questions of agency. The voice we hear is the teacher's, or at best the student's voices filtered through the teacher. This excerpt clearly narrates 
the children's progress as fulfilling a task. As such it paints a picture of good students doing what they were told. Moreover, the text provides an image of the teacher and the project excelling in their tasks. It can, thus, be understood as the teacher's voice reporting the desired progress to the project designers and researchers.

In the school context, the students' visual creations cannot be considered spontaneous or not goal-oriented, as in the romantic view of the innocent eye. As Einarsdottir et al. (2009, 221-222) note in their article on drawings as a means to tap into children's perspectives:

Teachers and the classroom context are influential factors in the generation of drawings and conversations. When the teacher introduces the task to the whole class, children clearly identify it as an academic task, potentially open to correction or assessment [...] We should not be surprised then, if children completing the activity with their teacher may be constrained by regarding it as a work sample.

In the light of this, researchers should be careful when using artifacts produced by children to gain insights into children's understandings and perspectives. Contextual factors such as the teacher's influence, existing curricula, and institutional practices in general should not be overlooked in analyses of such artifacts. Recordings of what students were saying or doing while drawing provide valuable background information for researchers in this regard (Ivashkevich 2009). Yet even the process of asking children to explain their drawings cannot avoid adult interpretation as "children can become quite adept at giving information that is required to complete the task" (Einarsdottir et al. 2009, 219).

In our research, we see the students as creators of artistic content and as social actors driven by their own interests. As creators of the artifacts, they retained the intellectual property of their work. They also collaborated together to choose artifacts that could be shared in the project website's gallery. This reflects the fact that listening to the student's voices has been a central aim of the project all along. Students were, for example, also consulted in the selection of cultural texts to determine which ones might be suitable to be discussed in classrooms.

Yet in our analysis we present the artifacts without reference to the individual maker's identity. In this, we adhere to confidentiality and data protection principles that seek to protect the identities of individual 
research subjects. This dual role of the students as both active participants, whose voices should be heard, and research subjects or children to be protected embodies an ethical problem faced by researchers studying child art in general (Kairavuori 2019; Pennanen 2019). As creators, children should be able to take credit for their work by being named. As research subjects and children, they should, however, be treated as vulnerable and in need of protection. Hence we, as adult researchers, use different "lenses" to navigate the two roles of the students. In general, we treat them as competent producers of the artifacts, but when it comes to reporting the study outcomes, we approach them as vulnerable and use protective measures such as anonymization (Clark 2005, 489).

Our sociocultural approach, then, is to consider the sociocultural contexts of both the creative activity and the analysis of the resulting artifacts. We acknowledge children's agency and look at the cultural influences and ideas transmitted via their visual expressions. In the end, the freedom of self-governed drawing or drawing as play is easily subordinated to the use of drawing as a tool to fulfil a preordained task. The result is a somewhat biased image of the thoughts and ideas of the child participants in this study. As Wood and Hall $(2011,280)$ put it "children's exercise of power, agency, risk and subversion sits uncomfortably with the normative and socially approved developmental goals in curriculum frameworks." This is the case in research projects that have a pedagogical orientation. As Clark $(2005,491)$ reminds us, "participation [... implies a sharing of power."

\section{REFERENCES}

Ahmad, J. F. 2018. "Children's Drawings in Different Cultures: An Analysis of Five-year-old Jordanian Children's Drawings." International Journal of Early Years Education 26 (3): 249-258.

Arnheim, R. 1954. Art and Visual Perception: The Psychology of the Creative Experience. 1974 expanded and revised edition. Berkeley, CA: University of California Press. https://monoskop.org/images/e/e7/Arnheim_Rudolf_ Art_and_Visual_Perception_1974.pdf.

Clark, A. 2005. "Listening to and Involving Young Children: A Review of Research and Practice." Early Child Development and Care 175 (6): 489-505.

Coates, E., and A. Coates. 2011. "The Subjects and Meanings of Young Children's Drawings." In Exploring Children's Creative Narratives, edited by D. Faulkner and E. Coates, 86-110. Oxon: Routledge. 
Cohn, N. 2014. "Framing 'I Can't Draw": The Influence of Cultural Frames on the Development of Drawing." Culture \& Psychology 20 (1): 102-117.

Corsaro, W. A. 1992. "Interpretive Reproduction in Children's Peer Cultures." Social Psychology Quarterly 55 (2): 160-177.

Cox, S. 2005. "Intention and Meaning in Young Children's Drawing." International Journal of Art \& Design Education 24 (2): 115-125.

Deguara, J., and C. Nutbrown. 2018. "Signs, Symbols and Schemas: Understanding Meaning in a Child's Drawings." International Journal of Early Years Education 26 (1): 4-23.

Deguara, J. 2015. “Meaning-Making in Young Children's Drawings.” PhD diss., University of Sheffield, UK.

Einarsdottir, J., S. Dockett, and B. Perry. 2009. “Making Meaning: Children's Perspectives Expressed Through Drawings." Early Child Development and Care 179 (2): 217-232.

Fineberg, J. 1998. "Modernism and the Art of Children." The Chronicle of Higher Education 44 (29): B8-9.

French, J. 1956. "Victorian Responses to Children's Art." College Art Journal $15(4): 327-333$.

Gernhardt, A., H. Rübeling, and H. Keller. 2013. “This Is My Family' Differences in Children's Family Drawings Across Cultures." Journal of Cross-Cultural Psychology 44 (7): 1166-1183.

Golomb, C. 1993. "Rudolf Arnheim and the Psychology of Child Art." Journal of Aesthetic Education 27 (4): 11-29.

Hall, S., ed. 1997. Representation: Cultural Representations and Signifying Practices. London: Sage and The Open University.

Haraway, D. J. 1991. "Situated Knowledges. The Science Question in Feminism and the Privilege of Partial Perspective." Simians, Cyborgs and Women. The Reinvention of Nature, 183-201. New York: Routledge.

Hopperstad, M. H. 2008. "Relationships Between Children's Drawing and Accompanying Peer Interaction in Teacher-initiated Drawing Sessions." International Journal of Early Years Education 16 (2): 133-150.

Ivashkevich, O. 2009. "Children's Drawing as a Sociocultural Practice: Remaking Gender and Popular Culture." Studies in Art Education: A Journal of Issues and Research 51 (1): 50-63.

James, A. 2007. "Giving Voice to Children's Voices: Practices and Problems, Pitfalls and Potentials." American Anthropologist 109 (2): 261-272.

James, A., and A. Prout. 1997. Constructing and Reconstructing Childhood: Contemporary Issues in the Sociological study of Childhood, 2nd ed. London: Falmer Press.

Kairavuori, S. 2019. “Lasten oikeudet kuviin!” In Jälkikuvia, kuvan jälkiä: Lasten ja nuorten taiteen tallentaminen ja tutkiminen, edited by Venäläinen, 
P., J. Lindholm, S. Kairavuori, and S. Ylönen, 39-62. Helsinki: Nuorisotutkimusverkosto.

Kellner, D. 1995. Media Culture: Cultural Studies, Identity and Politics Between the Modern and the Postmodern. London: Routledge.

Kiil, K. 2009. "Kielletyt kuvat: suomalais- ja virolaisnuorten piirtämällä esittämät kielletyt aiheet." PhD diss., Aalto University, Department of Art, Finland. http://urn.fi/URN:ISBN:978-952-60-3652-6.

Kress, G., and T. van Leeuwen. 2006. Reading Images: A Grammar of Visual Design, 2nd ed. London: Routledge.

Leeds, J. A. 1989. "The History of Attitudes Toward Children's Art." Studies in Art Education 30 (2): 93-103.

Lowenfeld, V. 1957. Creative and Mental Growth, 3rd ed. New York: Macmillan. Digitized by the Internet Archive in 2019 with funding from the University of Alberta Libraries. https://archive.org/stream/creativementalgr00lowe_0? $\mathrm{ref}=\mathrm{ol}$.

Mavers, D. 2011. Children's Drawing and Writing: The Remarkable in the Unremarkable. London: Routledge.

Mayall, B. 2002. Towards a Sociology for Childhood: Thinking from Children's Lives. Buckingham: Open University Press.

Nikoltsos, C. 2001. "Researching Children's Art: Systematic Observations of the Artistic Skills of Young Children." Educational Resources Information Center, US. https://files.eric.ed.gov/fulltext/ED449899.pdf.

Ostrofsky, J. 2015. "Developmental and Geographic Analyses of Spatial Biases in Face Drawings Produced by Children." Empirical Studies of the Arts 33 (1): 3-17.

Pennanen, L. 2019. “Omat nimet kirjoissa?” In Jälkikuvia, kuvan jälkiä: Lasten ja nuorten taiteen tallentaminen ja tutkiminen, edited by Venäläinen, P., J. Lindholm, S. Kairavuori, and S. Ylönen, 63-85. Helsinki: Nuorisotutkimusverkosto.

Pohjakallio, P., and T. Pusa. 2019. "Kuvia kaivamassa." In Jälkikuvia, kuvan jälkï̈: Lasten ja nuorten taiteen tallentaminen ja tutkiminen, edited by Venäläinen, P., J. Lindholm, S. Kairavuori, and S. Ylönen, 19-28. Helsinki: Nuorisotutkimusverkosto.

Qvortrup, J. 1994. Childhood Matters: Social Theory, Practice and Politics. Aldershot: Avebury.

Rose, G. 2001. Visual Methodologies: An Introduction to the Interpretation of Visual Materials. London: Sage.

Senzaki, S., T. Masuda, and K. Nand. 2014. "Holistic Versus Analytic Expressions in Artworks: Cross-Cultural Differences and Similarities in Drawings and Collages by Canadian and Japanese School-Age Children." Journal of Cross-Cultural Psychology 45 (8): 1297-1316. 
Tisdall, E. K. M., and S. Punch. 2012. "Not So 'New'? Looking Critically at Childhood Studies." Children's Geographies 10 (3): 249-264.

Venäläinen, P. 2019. "Katse lasten ja nuorten taiteeseen.” In Jälkikuvia, kuvan jälkiö, edited by P. Venäläinen, J. Lindholm, S. Kairavuori, T. Pusa, and S. Ylönen, 9-18. Helsinki: Nuorisotutkimuksen verkosto.

Wood, E., and E. Hall. 2011. "Drawings as Spaces for Intellectual Play." International Journal of Early Years Education 19 (3-4): 267-281.

Open Access This chapter is licensed under the terms of the Creative Commons Attribution 4.0 International License (http://creativecommons.org/licenses/ by $/ 4.0 /)$, which permits use, sharing, adaptation, distribution and reproduction in any medium or format, as long as you give appropriate credit to the original author(s) and the source, provide a link to the Creative Commons license and indicate if changes were made.

The images or other third party material in this chapter are included in the chapter's Creative Commons license, unless indicated otherwise in a credit line to the material. If material is not included in the chapter's Creative Commons license and your intended use is not permitted by statutory regulation or exceeds the permitted use, you will need to obtain permission directly from the copyright holder.

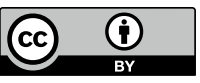

